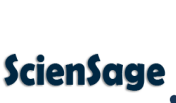

Journal of Advanced Scientific Research

Available online through https: / /sciensage.info
ISSN: 0976-9595

Short Communication

DOI: $10.55218 /$ JASR. 202213147

\title{
OREOCHROMIS MOSSAMBICUS TREATED WITH TRICYCLAZOLE (75\%) FUNGICIDE: A STUDY OF ACUTE TOXICITY AND BIOCHEMICAL ANALYSIS
}

\author{
Madhavi Mookan ${ }^{1}$, Noornissabegum Magbooljan *1, Rekha Vijayakumar ${ }^{2}$ \\ ${ }^{1}$ Post graduate and Research Department of Zoology, Ethiraj College for Women, Chennai, Tamilnadu, India \\ ${ }^{2}$ D.K.M. College for Women (Autonomous), Vellore-1, Tamilnadu, India \\ *Corresponding author: noori2608@gmail.com
}

\begin{abstract}
The goal of this study was to assess the acute toxicity and biochemical changes on Oreochromis mossambicus exposed to fungicide Tricyclazole. Within the acute toxicity test, $96 \mathrm{hr} \mathrm{LC}_{50}$ values of Tricyclazole were assessed to be $13.2 \mathrm{ppm}$, and biochemical parameters such as carbohydrate and glycogen levels were found to be dose-dependent decreases in all experimental groups, whereas cholesterol and protein levels were found to be dose-dependent increases in all experimental groups. The changes within the biochemical alterations in Oreochromis mossambicus can be used as the warning indications that their existence in their natural environment may be jeopardized. Hence, the current study reveals that the employment of Tricyclazole $75 \%$ pesticide product was classified among substances harmful to fish. The buildup of the fungicide within the muscle tissue in fishes might be hazardous to living organisms.
\end{abstract}

Keywords: Tricyclazole, Acute toxicity, Biochemical analysis, Carbohydrate, Protein, Cholesterol, Glycogen, Oreochromis mossambicus.

\section{INTRODUCTION}

Chemicals are a necessary component of man's life in order to improve his standard of living. The impact of chemical pollution has focused almost exclusively on the standard priority of pollutants, particularly those acutely toxic carcinogenic pesticides and industrial intermediates displaying persistence within the environment. Because of the exponential increase in human exposure to new synthetic chemicals, pollution-related disorders may become increasingly widespread. Pesticides have been dubbed the most harmful polluters of the aquatic environment [1].

Fungicides (such as tricyclazole and propiconazole) that are used to boost crop output eventually end up in the aquatic ecosystem. Tricyclazole is a systemic fungicide used to treat blast illnesses in rice caused by Pyricularia oryzae. It's also used in agriculture to treat fruits, vegetables, cereals, and seeds, as well as in medicine to treat fungal infections both locally and systemically. The fungicides are believed to have little toxicity to nontarget creatures, but they are known to accumulate in food chains and higher-level organisms, including humans, following long-term exposure. According to Palanikumar et al. [2] the Government of India encourages the widespread use of pesticides, insecticides, herbicides, and fungicides to increase crop production in order to meet the demand of the population. Pesticide use in the agroecosystem has resulted in global environmental contamination, with only 0.1 percent of pesticides applied reaching their target pests, while the remaining 99.9 percent end up in various components of the environment [3].

Chemical pesticide residues are highly hazardous and are ingested by a variety of smaller organisms before reaching higher organisms via food chains within the ecosystem. As a result, the entire ecosystem is polluted, posing biological risks. Pesticides applied on agriculture fields drain into the aquatic environment, affecting non-target creatures such as fish that serve as a food supply [4]. Fish alone provides around $80 \%$ of the animal protein in our diet [5]. Fish eating, on the other hand, can sometimes result in disease owing to infection or intoxication. Because they play various functions in the trophic web, collect toxic compounds, and respond to low mutagen doses, fish are widely utilized as sentinel organisms in ecotoxicological investigations [6].

The use of fish biomarkers as pollution indices is becoming more common, and it can help with early diagnosis of aquatic environmental issues [7]. Therefore, the current study looks into the acute toxicity and 
biochemical response of tricyclazole fungicide on Oreochromis mossambicus, an exotic euryhaline fish.

\section{MATERIAL AND METHODS}

\subsection{Collection of fish}

O.mossambicus [8] was found in abundance in both freshwater and brackish water locations in and around Chennai. Fish were collected from Vyasarpadi (local) pond in Chennai throughout the study to ensure that the population was identical and uniform size within the load range of $8 \pm 2 \mathrm{~g}$ fishes were used.

\subsection{Density of fish}

According to Muirhed Thomson [9] and Holden [10], $\mathrm{LC}_{50}$ maintained a constant ratio of fish biomass to water volume by using $1 \mathrm{~g}$ weight/ 1 litre of water to minimize differences in toxicity owing to density and oxygen depletion.

\subsection{Test Chemical}

The systemic fungicide tricyclazole (75\%) technical grade was obtained from Heranba industries, Bombay.

\subsection{Acute Study}

The fatality rate was monitored and reported at 24-hour, 48-hour, 72-hour, and 96-hour intervals. Finney's [11] approach was used to calculate the $\mathrm{LC}_{50}$, in which the probit mortality was plotted against the log of pesticides.

\subsection{Bio-Chemical Analysis}

The fish of the various groups were decapitated and preserved in ice for postmortem alterations at the conclusion of the testing period. Muscle tissue was dissected and weighed, with the needed amount of tissue being used for various biochemical assays. The total cholesterol content of muscle tissue was calculated [12]. The entire muscle protein was calculated using a span diagnostic kit, as described [13]. The Roe approach was used to calculate carbohydrate and glycogen [14].

\section{RESULTS}

\subsection{Acute study}

The dose mortalities experiments were carried out for 96 hours with 75 percent tricyclazole, and the $\mathrm{LC}_{50}$ of tricyclazole was found to be $13.2 \mathrm{ppm}$ in the fish $O$. mossambicus. The fish's 75 percent survival rate against Tricyclazole was graphically shown (Fig. 1). $O$. mossambicus was observed to swim and jump swiftly and repeatedly after the injection of the systemic fungicide tricyclazole 75 percent. They became lethargic over time, with short movements surfacing for gulping in air, and were discovered to be restless, with an irregular circular movement and a thick layer of mucus released. They eventually sank to the bottom, losing their equilibrium.

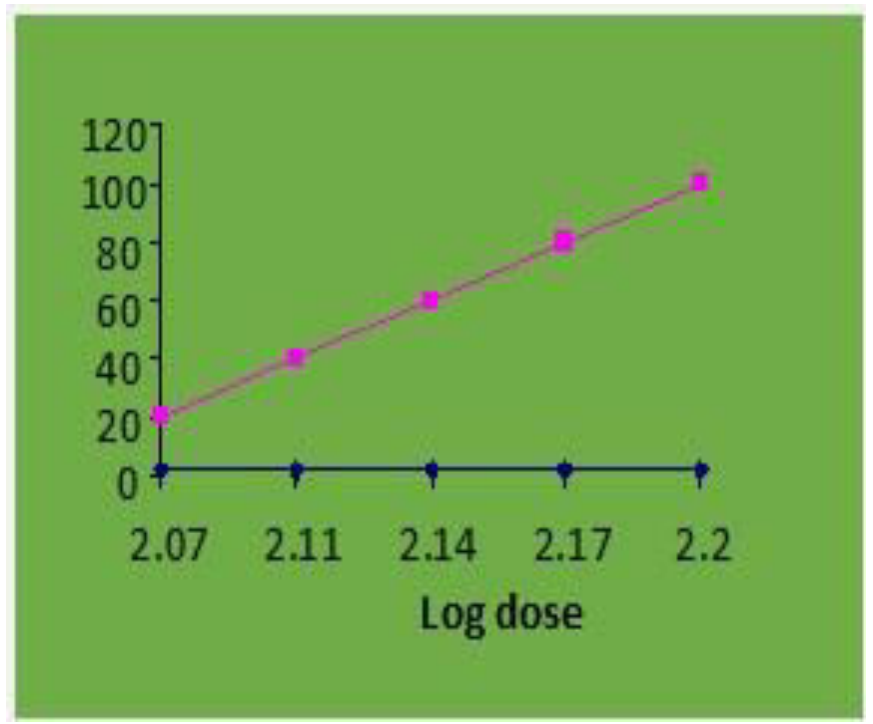

Fig. 1: Probit kill of Oreochromis mossambicus

\subsection{Bio-Chemical Analysis}

Estimation of cholesterol and total protein in all experimental groups when compared to the control value, showed a dose-dependent increase whereas estimation of carbohydrate and glycogen level in all experimental groups showed a dose-dependent drop when compared to the control value. (Fig.2 a-d).

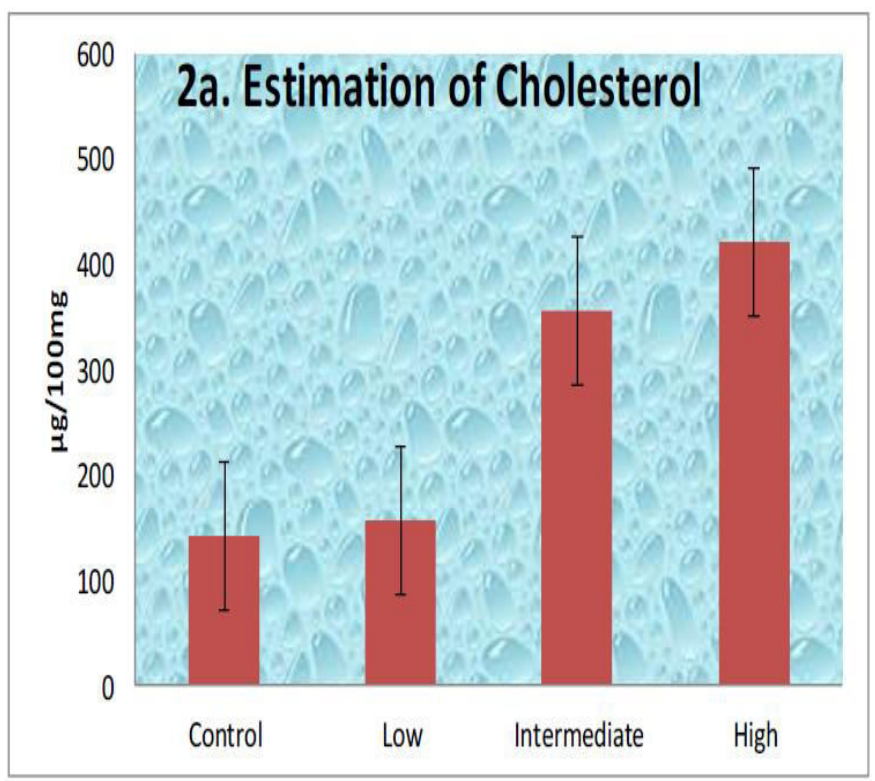



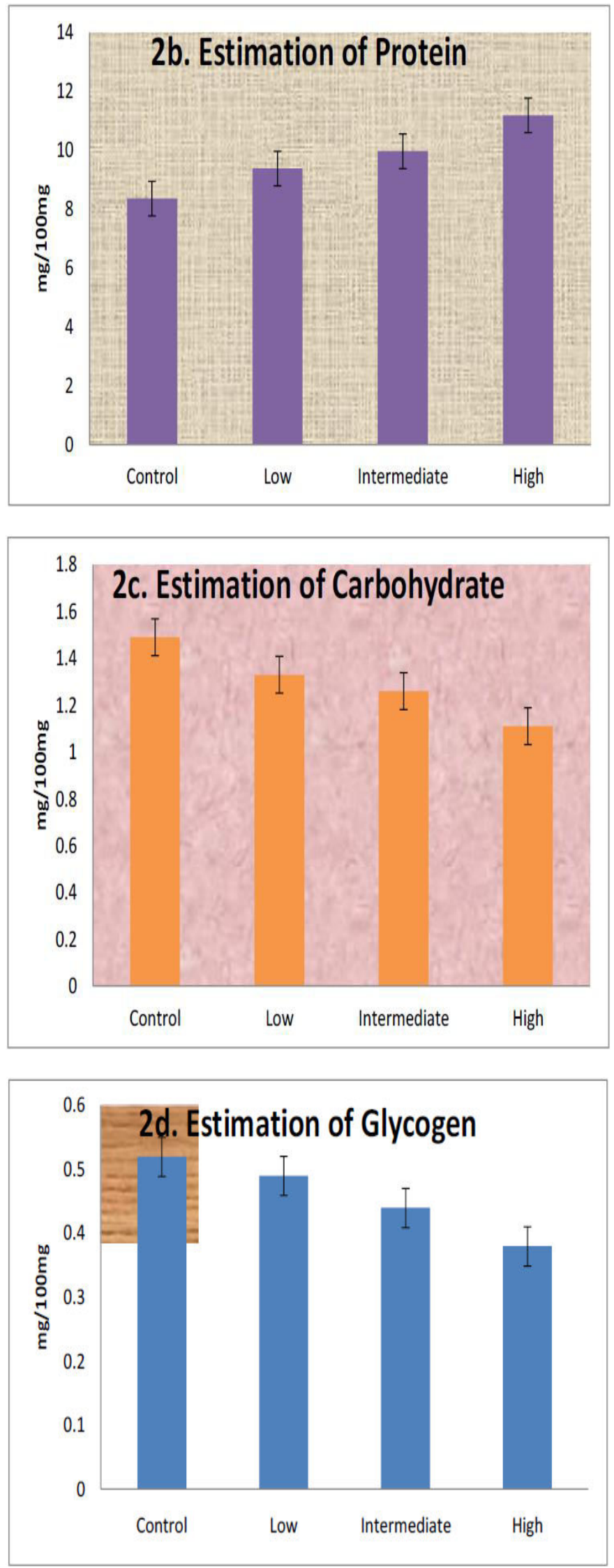

Fig. 2: Biochemical values of muscle tissue exposed to Tricyclazole (75\%)

\section{DISCUSSION}

Non-target consequences are common when changes in the chemical composition of the natural aquatic environment affect the behavioural and physiological systems of the inhabitants [15]. The $\mathrm{LC}_{50}$ measurements are used to determine the pesticide's effect on the target species. According to Singh [16] assessing fungicide sensitivity and damage to specific organs/systems of an animal appears to necessitate toxicity testing. Such observations indicate the underlying physiological state of the organs and tissues as a result of various diseases in fish [17].

The current $\mathrm{LC}_{50}$ study of tricyclazole 75 percent for 96 hours in O.mossambicus was determined to be $13.2 \mathrm{ppm}$, which agrees with previous findings of scientists [18, 19], Nimai Chandra Saha et al. [20] stated that $\mathrm{LC}_{50}$ values of tricyclazole in Punctius ticto $(12.95 \mathrm{mg} / \mathrm{l})$, Clarius batracus - adult $(14.36 \mathrm{mg} / \mathrm{l})$ and fingerlings $(14.04 \mathrm{mg} / \mathrm{l})$. Thus, differences in a fish's sensitivity to different pesticides could be linked to changes in survival capacity.

According to Jagadish Chandranan and sahai [21], weight, time spent in contact with the chemical, age, sex, weather conditions, and other factors will all influence the outcome. Propiconazole a triazole fungicide had the following $\mathrm{LC}_{50}$ values (in $\mathrm{ppm}$ ) for freshwater species such as Bluegill - 1.3 to 10.2, Carp - 6.8 to 21.0, Rainbow trout -0.9 to 13.2 , Catfish -2.0 to $5 \%$, and Fat Head minnow - 7.6 [22]. Furthermore, due to differences in the mode of action of pesticides and differences in the fish's response to pesticides, the $\mathrm{LC}_{50}$ values vary from species to species for the same pesticide and different pesticides for the same species.

Gill opercular movements increased at initially to support greater physiological activity in stressful conditions, but thereafter decreased due to gill mucus accumulation [23]. Excessive mucous secretion all over the body surface of Mancozeb-exposed fish was likely owing to a breakdown of the pituitary gland's regulatory mechanism over through the integument on stress owing to excessive toxicant concentrations, which confirms the current findings of Saha et al. [20].

The hyperexcitability of fungicide-treated $O$. mossambicus was most likely a result of a desire to avoid and escape the stress of Mancozeb poisoning [20, 24]. Other researchers had previously seen the breakdown of equilibrium in Clarius batracus treated with Mancozeb to greater concentrations [18]. A dysfunction of the central nervous system was the most likely cause [25].

Cholesterol is a type of lipid that belongs to the sterol family of compounds. Due to the lipophilic nature of 
pesticides and their residues building up in tissues, a rise in cholesterol is also expected. In the present study, cholesterol level increased when compared to a control value, similar results were observed by Hadi et al [26] in freshwater fish, Tilapia zilli, exposed to aluminium, [27] in metal-intoxicated Oreochromis niloticus as well as [28] in Oreochromis niloticus exposed to copper, lead, and cypermethrin treatments, both short and long term. Triglycerides and cholesterol are known to play a role in total lipid increase. They came to the conclusion that hepatic and renal failure, which causes cholesterol to be released into the bloodstream, may cause cholesterol levels to rise. After being exposed to cypermethrin, Rhamdia quelen developed hypercholesterolemia [29].

A dose-dependent increase in protein content was reported in the current investigation. A rat equivalent experiment demonstrated an increase in total protein levels [30]. According to Dulsyfatima [31], certain substances have an affinity for plasma proteins, and a metabolic imbalance results in an increase in protein levels in muscle tissue. Protein aids in the detoxification of toxicants that enter the animal body by assisting in the creation of microbial detoxifying enzymes [32]. The findings show that contaminants have a different effect on muscle protein levels than on other tissues. Carbohydrates, when available in adequate amounts, are subjected to an oxidative process for energy recovery, which helps to conserve proteins for tissue construction [33]. The observations of a decrease in carbohydrate content in Catla catla tissues with increasing pesticide concentrations appear to stem from the fish's quick consumption of carbohydrate to meet their energy demands under stress.

Carbohydrates are the primary source of energy for stressed fish, with protein acting as a backup source of energy during chronic stress, which may appear to reflect carbohydrate decreases [34]. Catla catla subjected to pyrethroid fenvalerate showed biochemical and enzymatic alterations, as well as a decrease in glycogen [35]. Toxicant stress causes biochemical changes in the tissues, causing disturbances in metabolism and glycogen levels. At the cellular level, enzymes cause growth retardation, fecundity reduction, and organism longevity [36]. According to Yang et al. [37] a biochemical method has been suggested as a technique of providing early warning of potentially hazardous alterations in stressed fish.

Pandit et al. [38] investigated acute toxicity and its responses to various biomarkers in the freshwater fish Channa punctatus, which aids in the identification of a toxicant's mode of action as well as information on doserelated mortality, which can be used to set dose levels for repeated-dose studies. Tricyclazole use in paddy culture has negative effects on various parameters of aquatic nontarget species, and sub-lethal dosages of tricyclazole cause significant serum biochemical abnormalities in Channa punctatus, which may jeopardise the species' survival in its natural habitat.

\section{CONCLUSION}

The effects of pesticides on the natural ecosystem are demonstrated by the results of $O$. mossambicus exposure to Tricyclazole fungicide, as in several stages of physiological and biochemical metabolism in fishes, the distribution and concentration of energy-rich biochemicals glucose, glycogen, protein, and lipid appear to reflect their function in storing nature's energy. As a result, fish can be used as excellent water quality monitors for pesticide disposal from agricultural run-off into natural bodies of water, thereby lowering the risk to non-target animals and aquatic ecosystems.

\section{Conflict of interest}

No conflict of interest

\section{REFERENCES}

1. Mushigeri SB, David M. J.Ecotoxical Environ.Monit, 2003; 13(3):211-214.

2. Palanikumar L, Kumaraguru AK, Ramakritinan CM, Anand M. Int. J. Environ. Sci. Technol. 2014; 11: 765-774.

3. Tripathi G, Shasmal J. Pest Biochem Physiol, 2011; 99:215-220.

4. Amitha Susan T, Veeraiah K, Tilak KS. J.Ecobiol., 1999; 11(2):109-113.

5. Rubbi SM, Muslemuddin M, Wahed A. (1978): The present status of fish technology and inspection in Bangladesh. Paper presented to the FAO/Danida in Bangladesh. Paper presented to the FAO/Danida.

6. Cavas T, Ergene-Gozukara S. Environ. Mol. Mutagen, 2005 ; 46:64-70.

7. Van Der Oost R, Beyer J, Vermeulen NPE. Environ Toxicol Pharm, 2003; 13:57-149.

8. Trewaves E. J.Limnol.Soc, 1981; 7(1):42.

9. Muirhed Thomson RC. (1971). "Pesticides and freshwater fauna”. Academic press. London, New York.

10. Holden AN. Environmental pollution by pesticides. 1973; 213.

11. Finney DJ. "Probit analysis" $3^{\text {rd }}$ edn., Cambridge University Press, Cambridge, London. 1971. 
12. Allain CC, Poon L, Chan SG, Richmond W. Clinical chemistry, 1974; 20:470.

13. Doumas BT, Watson WA, Biggs AG. Clinical Chemistry Acta, 1971; 31:87.

14. Roe JH. J.of Biol.Chem, 1955; 212:335-343.

15. Sambasiva Rao KRS. Pesticide impact on fish metabolism. 1999; 129-149.

16. Singh PA, Singh S, Bhartiya P, Yadav Y. Adv Biores. 2010; 1(1):177-181.

17. Obomanu FG, Gabriel UU, Edori OS, Emetonjor JN. J Medi Plants Res. 2009; 3(12):995-1001.

18. Srivastava P, Singh A. Journal of Biology and Earth Sciences, 2013; 3(2):228-235.

19. Sharma MR, Mushtaq R, Allayie SA, Vardhan H. Journal of International Academic research for Multidisciplinary, 2016; 4(2):132-138.

20. Nimai Chandra Saha, Santosh Kumar Giri, Nishan Chatterjee, Surjyo Jyoti Biswas, Suman Bej. Int. J. Adv. Res. Biol. Sci, 2016; 3(6):40-44.

21. Jagadish Chandranan, Sahai S. Trends in pollution and toxicology. 1958;

22. Extension Toxicology Network (EXTONET). A Pesticide information project of cooperative extension offices of Cornell University", Michigan state University, Oregon state university and university of California, Davis, 1977.

23. David M, Mushigeri S, Prashanth MS. Geobios, 2002; 29:25-32.

24. Bhat BA, Bhat IA, Vishwakarma S, Verma A, Saxena G. Curr. World. Environ, 2012; 7(1):157-161.
25. Sikka SC, Gurbuz, N. Toxicol. of Carbamate Compounds, 2006; 447-462.

26. Hadi AA, Shokr AE, Alwan SF. Journal of sciences and its applications, 2009; 3:33-41.

27. Oner M, Atli G, Canli M. Environ Toxicol Chem. 2008; 27(2):360-366.

28. Firat O, Cogun HY, Yuzereroglu TA, Gok G, Firat O, Kargin F. et al. Fish Phy Biochem. 2011; 37: 657-666.

29. Borges A, Scotti LV, Siqueira DR, Zanini R, Amaral F, Jurinitz DF et al. Chemosphere, 2007; 69:920-926.

30. Pest Management Regulatory Agency. Proposel Regulatory Decision document. 1995.

31. Dulsyfatima RP, Meyyan S, Prasannakumar KM, Narayanan K, et al. I Editon.Pub.Saras Publication Innovation Printers, Nagercoil, 1993.

32. Ramasamy M. Environ.Ecol, 1987; 5:633-637.

33. Nair PKG, Achar KP, Hedge MJ, Prabhu SG. (A Text Book of Biology, $13^{\text {th }}$ revised edition, Himalaya Publishing House, Mumbai. 2004.

34. Nagaraj G, Sarma ALN. J.Ecotoxicol. Environ Monit., 2008; 18(4):359-371.

35. Bakthavathchalam R, Srinivasan Reddy Y. Indian. J.Environ. Hith,, 1985; 27(2):159-163.

36. Tilak KS, Veeraiah K, Jhansi Lakshmi S. J.Environ Biol, 2002; 23(4):377-381.

37. Jee-Lee yang, Hon -Chen. Zool. studies, 2003; 42(3):455-461.

38. Dina Nath Pandit, Usha Rani. International Journal of Fisheries and Aquatic Studies, 2019; 7(6):246-250. 